\title{
ANALISIS RISIKO KESELAMATAN DAN KESEHATAN KERJA DI LABORATORIUM KIMIA TERPADU POLITEKNIK KESEHATAN PADANG TAHUN 2019
}

Analysis of occupational health and safety risks in the integrated chemical laboratory of padang health polytechnic in 2019

Awaluddin', Miladil Fitra ${ }^{2}$, Asep Irfan ${ }^{3}$, Evino Sugriarta ${ }^{4}$

1,2,3,4 Politeknik Kesehatan Padang

miladilfitra@gmail.com/ Hp.08126720352

\begin{abstract}
The laboratory at the Poltekkes Padang as a means of supporting learning and research, also has dangers and risks that can lead to health and safety risks. The biggest source of danger comes from chemicals used during practicum, so an understanding of the types of chemicals is needed so that those who work with these materials can be more careful and know how to deal with it in the event of an accident. The laboratory at the Padang Health Polytechnic is one of the laboratories used to support learning and research, which also has dangers and risks that can cause health and safety risks. There is no risk assessment activity in the laboratory and there was a fire at the Dental Nursing Department Campus on October 18, 2018 in the clinic room and the results of the initial survey in the Padang laboratory were still there / it was seen that one electrical plug was used by several cable branches to use this electricity later. may cause fire due to short circuit. Based on the description above, the problems to be investigated can be formulated, namely: What is the risk of Occupational Safety and Health (K3) in the laboratory at the Health Polytechnic of Padang, Siteba Padan Campus. The research objective was to conduct a risk analysis for Occupational Safety and Health (OSH) at the Integrated Chemistry Laboratory at the Padang Siteba Campus Health Polytechnic in 2019. This research will carry out hazard identification and risk analysis, the hazard identification method uses Task Risk Analysis. For risk analysis is carried out using a semiquantitative risk analysis method which includes risk identification, determination of the value of the consequences, likelihood, and exposure of each safety and health risk which is then used to determine the level of risk in the laboratory. 35 (Very high $=1$, Priority $1=3$, Substantial $=18$, Priority3 $=9$ and acceptable $=4$ ) the risk of Integrated Chemical labor at Padang Health Polytechnic is therefore required SOP for each room and during practice and personal protective equipment in accordance with the activity that will be done.
\end{abstract}

Keywords: Laboratory, Occupational Health and Safety Risk Analysis, Task Risk Analysis

\section{ABSTRAK}

Laboratorium di Poltekkes Padang sebagai sarana penunjang dalam belajar dan penelitian, juga memiliki bahaya dan risiko yang dapat menyebabkan timbulnya risiko kesehatan dan keselamatan. Sumber bahaya terbesar berasal dari bahan- bahan kimia yang digunakan selama praktikum, maka diperlukan pemahaman mengenai jenis bahan kimia agar yang bekerja dengan bahan-bahan tersebut dapat lebih berhati-hati dan tahu bagaimana cara menanggulanginya jika terjadi kecelakaan. Laboratorium di Politeknik Kesehatan Padang merupakan salah satu laboratorium yang digunakan sebagai penunjang dalam pembelajaran dan penelitian, yang juga memiliki bahaya dan risiko yang dapat menyebabkan timbulnya risiko kesehatan dan keselamatan. Pada laboratorium tersebut belum ada kegiatan penilaian risiko dan telah terjadinya kebakaran di Kampus Jurusan Keperawatan gigi pada tanggal 18 Oktober 2018 di ruang klinik dan hasil survey awal di labor padang masih ada/terlihat satu colokan listrik dipakai beberapa cabang kabel untuk pemakaian arus listrik hal ini nantinya bisa mengakibatkan kebakaran karena arus pendek. Berdasarkan uraian di atas maka dapat dirumuskan masalah-masalah yang akan diteliti yaitu: Bagaimana risiko Keselamatan dan Kesehatan Kerja (K3) pada laboratorium di Politeknik Kesehatan Padang Kampus Siteba Padan. Tujuan penelitian melakukan analisis risiko Keselamatan dan Kesehatan Kerja (K3) pada laboratoriumKimia Terpadu di Politeknik Kesehatan Padang Kampus Siteba Padang tahun 2019. Penelitian ini akan dilakukan identifikasi bahaya dan analisis risiko, metode identifikasi bahaya menggunakan Task Risk Analysis. Untuk analisis risiko dilakukan dengan menggunakan metode analisis risiko semikuantitatif yang meliputi identifikasi risiko, penentuan nilai konsekuensi, kemungkinan (likelihood), dan pajanan (exposure) dari setiap risiko keselamatan dan kesehatan yang kemudian digunakan untuk mengetahui tingkat risiko di laboratorium.adapun Hasil penelitian ini didapat 35(Very high=1, Priority $1=3$, Substansial=18, Priority $3=9$ dan acceptable $=4$ ) risiko dari labor Kimia Terpadu Poltekkes padang oleh sebab itu diperlukan SOP setiap ruangan dan pada saat praktek serta alat pelindung diri yang sesuai dengan kegiatan yang akan dilakukan.

Kata Kunci: Analisis Risiko Keselamatan dan Kesehatan Kerja, Laboratorium, Task Risk Analisis

\section{PENDAHULUAN}

Gedung di Politeknik Kesehatan Kemenkes Padang terdiri dari ruangan kantor, ruangan kelas, ruangan pustaka, asrama, laboratorium dan bengkel kerja dari masing-masing ruangan tersebut yang paling berisiko terhadap gangguan kesehatan dan keselamatan kerja adalah laboratorium atau bengkel kerja.

Laboratorium merupakan tempat untuk melakukan percobaan, penelitian dan pengembangan. Bekerja dalam laboratorium sama halnya seperti bekerja di industri-industri lain, industri kimia, pertambangan, ataupun konstruksi, yang mengandung bahaya dan risiko keselamatan kerja. Di laboratorium biasanya menggunakan berbagai bahan kimia, peralatan gelas, dan juga instrumentasi khusus yang dapat menyebabkan terjadinya kecelakaan bila dilakukan dengan cara yang tidak tepat. Kecelakaan juga dapat terjadi karena kelalaian 
atau kecerobohan dalam bekerja, yang mengakibatkan orang tersebut cedera, atau bahkan dapat membuat celaka orangorang di sekitarnya ( Mutiara Ayu Asmara, 2012). Untuk tingkat universitas banyak kasus kecelakaan yang telah terjadi di laboratorium khususnya pada saat melakukan penelitian. Beberapa contoh kasus yang pernah terjadi di laboratorium, salah satunya yaitu kasus yang terjadi di laboratorium kimia San Isidro High School di Makati, Manila, pada tanggal 27 November 2006, campuran zat kimia mengeluarkan asap beracun yang menyebabkan 10 guru dan staf dibawa ke rumah sakit setelah beberapa saat mengalami muntah dan ruam kulit \{National Research Council, 2011). Pada 7 Januari 2010, kecelakaan di Laboratorium Departemen Kimia milik Universitas Texas Tech, akibat melanggar prosedur atau ketentuan penggunaan bahan kimia campuran nickel hydrazine perchlorate dalam melakukan penelitian hingga menyebabkan satu mahasiswa kehilangan tiga jarinya, perforasi pada mata, dan mengalami luka bakar di beberapa bagian tubuh (CSB, 2010). Kasus di Indonesia juga pernah terjadi di Universitas Indonesia yaitu kebakaran dan ledakan pada tahun 2005 di laboratorium yang menggunakan bahan kimia. Selain itu juga terdapat beberapa kecelakaan fisik dengan jangka tahun yang tidak tercatat dan disebabkan karena belum adanya pemahaman mengenai penggunaan peralatan dan bahan kimia secara aman (Majalah UI 2007).

Pada tanggal 18 Oktober tahun 2018 di Politeknik Kesehatan Padang Jurusan Keperawatan Gigi Bukittinggi Juga terjadi kebakaran di Laboratorium hal ini disebabkan oleh Konsleting Listrik atau terjadi arus pendek pada ruang klinik.

Laboratorium di Politeknik Kesehatan Padang merupakan salah satu laboratorium yang digunakan sebagai penunjang dalam pembelajaran dan penelitian, yang juga memiliki bahaya dan risiko yang dapat menyebabkan timbulnya risiko kesehatan dan keselamatan. Pada laboratorium tersebut belum ada kegiatan penilaian risiko dan telah terjadinya kebakaran di Kampus Jurusan Keperawatan gigi pada tanggal 18 Oktober 2018 di ruang klinik dan hasil survey awal di labor padang dan labor keperawatan gigi bukitting masih ada/terlihat satu colokan listrik dipakai beberapa cabang kabel untuk pemakaian arus listrik hal ini nantinya bisa mengakibatkan kebakaran karena arus pendek.. Oleh karena itu, penulis ingin melakukan Analisis risiko Keselamatan dan Kesehatan Kerja (K3) pada laboratorium di Politeknik Kesehatan Padang Kampus Siteba Padang dan Kampus Jurusan Keperawatan Gigi di Bukittinggi guna mengetahui tingkat risiko di laboratorium.

\section{METODE}

Pada penelitian ini akan dilakukan identifikasi bahaya dan analisis risiko. metode identifikasi bahaya menggunakan Task Risk Analysis. Untuk analisis risiko dilakukan dengan menggunakan metode analisis risiko semikuantitatif yang meliputi identifikasi risiko, penentuan nilai konsekuensi(Consequency), kemungkinan (likelihood/ probability), dan pajanan (exposure) dari setiap risiko keselamatan dan kesehatan yang kemudian digunakan untuk mengetahui tingkat risiko di laboratorium dengan rumus: Nilai risiko/ Risk score= Consequency $x$ Exposure $x$ Probability (Santoso, H. 2014 dan Arvina N, dkk. 2012). Untuk lebih jelas dapat dilihat pada table berikut:

\begin{tabular}{lrr}
$\begin{array}{l}\text { Penilaian } \\
\text { (Consequency) }\end{array}$ & risiko & \multicolumn{2}{c}{ Konsekuensi } \\
Kuantitatif: & & Analisis Semi-
\end{tabular}

\begin{tabular}{|c|c|c|}
\hline Category & Description & Rating \\
\hline Catastrophe & $\begin{array}{l}\text { Bencana besar : kematian } \\
\text { massal, kerusakan permanen } \\
\text { pada lingkungan setempat }\end{array}$ & 100 \\
\hline Disaster & $\begin{array}{l}\text { Bencana : kematian, } \\
\text { kerusakan permanen yang } \\
\text { bersifat lokal terhadap } \\
\text { lingkungan }\end{array}$ & 50 \\
\hline $\begin{array}{l}\text { Very } \\
\text { Serious }\end{array}$ & $\begin{array}{l}\text { Sangat serius : cacat } \\
\text { permanen, penyakit kanker, } \\
\text { kerusakan lingkungan yang } \\
\text { bersifat sementara }\end{array}$ & 25 \\
\hline Serious & $\begin{array}{l}\text { Serius : efek serius pada } \\
\text { pekerja namun tidak bersifat } \\
\text { permanen, efek serius non } \\
\text { kanker, efek yang } \\
\text { merugikan bagi lingkungan } \\
\text { tapi tidak besar }\end{array}$ & 15 \\
\hline Important & $\begin{array}{l}\text { enting : membutuhkan } \\
\text { perawatan medis, terjadi } \\
\text { emisi buangan tapi tidak } \\
\text { mengakibatkan kerusakan }\end{array}$ & 5 \\
\hline Noticeable & $\begin{array}{l}\text { Tampak : luka atau sakit } \\
\text { ringan, sedikit kerugian } \\
\text { produksi, kerugian kecil pada } \\
\text { perlatan/mesin tapi tidak } \\
\text { berpengaruh pada produksi }\end{array}$ & 1 \\
\hline
\end{tabular}

Sumber: Arvina N, dkk. (2012) 
Jurnal Sulolipu : Media Komunikasi Sivitas Akademika dan Masyarakat

Vol. 20 No. 22020

e-issn : 2622-6960, p-issn : 0854-624X

Penilaian risiko Probability (likelihood) pada Analisis Semi-Kuantitatif:

\begin{tabular}{|c|l|c|}
\hline Probabilitas & \multicolumn{1}{|c|}{ Description } & Rating \\
\hline Almost Certain & $\begin{array}{l}\text { Terjadi Kemungkinan } \\
\text { yang paling sering }\end{array}$ & 10 \\
\hline Likely & $\begin{array}{l}\text { Kemungkinan terjadi } \\
\text { kecelakaan 50\%;50\% }\end{array}$ & 6 \\
\hline $\begin{array}{c}\text { Unusually but } \\
\text { possible }\end{array}$ & $\begin{array}{l}\text { Tidak biasa terjadi } \\
\text { namun mempunyai } \\
\text { kemungkinan untuk } \\
\text { terjadi }\end{array}$ & 1 \\
\hline $\begin{array}{l}\text { Remotely } \\
\text { Possible }\end{array}$ & $\begin{array}{l}\text { Kejadian yang sangat } \\
\text { kecil } \\
\text { kemungkinannya } \\
\text { untuk terjadi }\end{array}$ & $\begin{array}{l}\text { Tidak pernah terjadi } \\
\text { kecelakaan selama } \\
\text { tahun-tahun } \\
\text { pemajanan, namun } \\
\text { mungkin terjadi }\end{array}$ \\
\hline Conceivable & $\begin{array}{l}\text { Sangat tidak mungkin } \\
\text { terjadi }\end{array}$ & 0,1 \\
\hline $\begin{array}{l}\text { Pratically } \\
\text { Impossible }\end{array}$ & & \\
\hline
\end{tabular}

Sumber: Arvina N, dkk. (2012).

Penilaian risiko Pajanan (Exposure):

\begin{tabular}{|c|c|c|}
\hline Pemaparan & Description & Rating \\
\hline Continuously & $\begin{array}{l}\text { Terus menerus: } \\
\text { terjadi >1 kali } \\
\text { sehari }\end{array}$ & 10 \\
\hline Frequently & $\begin{array}{l}\text { Sering : terjadi } \\
\text { kira-kira } 1 \text { kali } \\
\text { sehari }\end{array}$ & 6 \\
\hline Occasionally & $\begin{array}{l}\text { Kadang-kadang: } \\
\text { terjadi } 1 \text { kali } \\
\text { seminggu } \\
\text { sampai } 1 \text { kali } \\
\text { sebulan }\end{array}$ & 3 \\
\hline Infrequent & $\begin{array}{l}\text { Tidak sering: } \\
\text { sekali dalam } \\
\text { sebulan sampai } \\
\text { sekali dalam } \\
\text { setahun }\end{array}$ & 2 \\
\hline Rare & $\begin{array}{l}\text { Tidak diketahui } \\
\text { kapan terjadinya }\end{array}$ & 1 \\
\hline Very rare & $\begin{array}{l}\text { Sangat tidak } \\
\text { diketahui kapan } \\
\text { terjadinya }\end{array}$ & 0,5 \\
\hline
\end{tabular}

Sumber: Arvina N, dkk. (2012).

Populasi pada penelitian ini adalah sarana dan prasarana Labor Serta Petugas Labor, Sampel pada penelitian ini adalah Total Sampling.

Teknik pengumpulan data menggunakan Analisis Semikuantitatif dan identifikasi bahaya dan Risiko menggunakan Task Risk Analysis. Penelitian akan dilaksanakan di Laboratorium Kimia Terpadu Politeknik Kesehatan Kemnkes Padang Kampus Siteba pada bulan Maret sd Oktober 2019

\section{Jumlah dan cara pengambilan subjek}

Populasi pada penelitian ini adalah sarana dan prasarana Labor Serta Petugas Labor, Sampel pada penelitian ini adalah Total Populasi dan teknik pengambilan sampel dengan cara Total sampling.

\section{Langkah-Langkah Penelitian}

Pengumpulan data menggunakan Task Risk Analysisuntuk identifikasi bahaya dan Risiko.

\section{Pengolahan dan analisis data}

Pengolahan data menggunakan metode Analisis Risiko semi kuantitatif dengan tingkat risiko/ level risiko sebagai berikut:

\begin{tabular}{|c|c|c|c|}
\hline $\begin{array}{c}\text { Risk } \\
\text { Level }\end{array}$ & Degree & Action & $\begin{array}{l}\text { Hierarchie of } \\
\text { control }\end{array}$ \\
\hline$>350$ & $\begin{array}{l}\text { Very } \\
\text { high }\end{array}$ & $\begin{array}{l}\text { Stop aktivitas } \\
\text { sampai risiko } \\
\text { dikurangi }\end{array}$ & Engineering \\
\hline $\begin{array}{l}180- \\
350\end{array}$ & Priority 1 & $\begin{array}{l}\text { Membutuhka } \\
\mathrm{n} \text { tindakan } \\
\text { perbaikan } \\
\text { segera }\end{array}$ & Administratif \\
\hline $70-180$ & $\begin{array}{l}\text { Substanti } \\
\text { al }\end{array}$ & $\begin{array}{l}\text { Membutuhka } \\
\mathrm{n} \text { tindakan } \\
\text { perbaikan }\end{array}$ & Pelatihan \\
\hline $20-70$ & Priority 3 & $\begin{array}{l}\text { Membutuhka } \\
\mathrm{n} \text { perhatian } \\
\text { dan } \\
\text { pengawasan }\end{array}$ & $\begin{array}{l}\text { Alat pelindung } \\
\text { diri }\end{array}$ \\
\hline$<20$ & $\begin{array}{l}\text { Acceptab } \\
\text { le }\end{array}$ & $\begin{array}{l}\text { Intensitas } \\
\text { kegiatan yang } \\
\text { menimbulkan } \\
\text { risiko }\end{array}$ & \\
\hline
\end{tabular}

HASIL

Dari hasil pengamatan dan wawancara dengan petugas labor hasil identifikasi risiko dan bahaya, analisis risiko dan evaluasi risiko dilabor kimia terpadu poltekkes padang sebagai berikut:

1) Pada kegiatan Mencuci alat-alat setelah pratikum dapat menimbulkan risiko bahaya fisik seperti tergores pecahan kaca dan Bahaya Kimia seperti terkena larutan (K2Cr2O7), dan dari hasil penilaian risiko didapat 3 risiko yaitu Priority 3 , Substantial dan Priority 1

2) Kegiatan Mengambil serbuk bahan kimia dan menimbang sampel di atas cawan petri dapat menimbulkan bahaya kimia serta berisiko terhirup bahan kimia saat sedang mengambil dan menaruh kewadah serta kontak bahan kimia, dan dari hasil penilaian risiko didapat 14 risiko yaitu 9 risiko substansial, 2 risiko priority $3, \quad 1$ risiko 
acceptable, 1 risiko priority 1 dan 1 risiko Very High

3) Kegiatan Mengambil larutan $\mathrm{HCl}$ pekat dengan pipet dapat menimbulkan bahaya kimia dan berisiko terhirup uap larutan atau terkena larutan, dan dari hasil penilaian risiko didapat 2 risiko yaitu 1 risiko substansial, dan 1 risiko priority 1

4) Kegiatan Memasukkan larutan ke dalam labu ukur dapat menimbulkan bahaya fisik seperti luka ringan dan bahaya kimia terkena larutan seperti terkena bahan kimia $\mathrm{Na}_{2} \mathrm{C}_{2} \mathrm{O}_{4}$, dan dari hasil penilaian risiko didapat 8 risiko yaitu 4 risiko substansial, 2 risiko priority 3 dan 2 risiko acceptable

5) Kegiatan Menambahkan aquadest ke dalam labu ukur dapat menimbulkan Bahaya fisik seperti tergores pecahan kaca dan dari hasil penilaian risiko didapat 1 risiko yaitu priority 3

6) Kegiatan Mengocok/membolak-balikkan labu takar dapat menimbulkan Bahaya fisik seperti tergores pecahan kaca dan dari hasil penilaian risiko didapat 1 risiko yaitu acceptable

7) Kegiatan Panaskan air untuk memanaskan larutan $\mathrm{Na}_{2} \mathrm{C}_{2} \mathrm{O}_{4}$ dapat menimbulkan Bahaya fisik seperti terkena air panas dan elektrik, dan dari hasil penilaian risiko didapat 2 risiko yaitu 1 risiko priority 1 dan 1 risiko substansial

8) Kegiatan Titrasi dapat menimbulkan Bahaya kimia seperti terkena larutan $\mathrm{HCL}$, EDTA, $\mathrm{KMnO}_{4}$, dan bahaya ergonomi seperti repetitif motion, dan dari hasil penilaian risiko didapat 4 risiko yaitu 2 risiko priority 3 dan 2 risiko substansial

\section{PEMBAHASAN}

Dari hasil penelitian dilakukan penilaian risiko berdasarkan teori dan temuan dilapangan dengan menggunakan metode analisis risiko semi kuantitatif serta menentukan tingkat/level risiko dan dampak yang timbul.

1) Pada kegiatan Mencuci alat-alat setelah pratikum didapat hasil penilaian berdasarkan teori dan temuan dilapangan yaitu 3 risiko sebagai berikut:

a. Risiko tergores pecahan kaca dengan nilai risiko 30 (priority 3 ) dengan dampak luka ringan ini bisa disebabkan karna bekerja kurang hatihati

b. Risiko kontak pada kulit bahan kimia K2Cr2O7 dengan nilai risiko 135 (substantial) dengan dampak kulit kemerahan bahkan bisa luka bakar. hal ini disebabkan mahasiswa tidak pakai sarung tangan pada saat pencucian.

c. Risiko kontak pada mata bahan kimia $\mathrm{K} 2 \mathrm{Cr} 2 \mathrm{O} 7$ dengan nilai risiko 225 (priority 1) ini bisa disebabkan karna mahasiswa tidak pakai sarung tangan pada saat pencucian dan dampak dari kegiatan ini bisa mengakibatkan luka ringan, kulit kemerahan, luka bakar akibat bahan kimia serta apabila terkena mata bisa pandangan menjadi kabur bahkan kebutaan

2) Pada Kegiatan Mengambil serbuk bahan kimia dan menimbang sampel di atas cawan petri didapat hasil penilaian berdasarkan teori dan temuan dilapangan yaitu 14 risiko sebagai berikut:

a. Risiko terhirup bahan kimia didapat 7 risiko yaitu 5 substansial dengan nilai risiko masing-masing 90 dan 2 priority 3 dengan nilai risiko masingmasing 45, ini disebabkan MSDS belum diterapkan dan masih ada melakukan praktek tidak sesuai SOP serta masker yang belum standar (memakai masker biasa) dan dampak dari kegiatan ini bisa mengakibatkan iritasi pada paru-paru disertai batuk dan sesak nafas terhirup $\mathrm{Na}_{2} \mathrm{CO}_{3}$, iritasi, korosif pada membran mucus terhirup $\mathrm{Na}_{2} \mathrm{C}_{2} \mathrm{O}_{4}$ ditandai dengan rasa terbakar, bersin /batuk dan mengiritasi saluran pernafasan apabila terhirup $\mathrm{KMnO}_{4}$.

b. Risiko terkena/kontak bahan kimia didapat 7 risiko yaitu 4 substansial (nilai risiko 2 item 90 dan 2 item 75), 1 priority 1 dengan nilai 270.1 very high dengan nilai 450 dan 1 acceptable dengan nilai 15 , ini disebabkan tidak pakai sarung tangan karet saat praktek, bekerja kurang hatihati, melakukan praktek belum sesuai SOP, tidak pakai safety googles saat praktek. Dampak dari kegiatan ini bisa mengakibatkan iritasi pada kulit dan mata bahkan kerusakan kornea dan buta apabila kontak dengan $\mathrm{Na}_{2} \mathrm{CO}_{3} /$ $\mathrm{ZnSO}_{4} \mathrm{MgSO}_{4} / \mathrm{Na}_{2} \mathrm{C}_{2} \mathrm{O}_{4} / \mathrm{H}_{2} \mathrm{C}_{2} \mathrm{O}_{4} / \mathrm{KMnO}_{4}$.

3) Kegiatan Mengambil larutan $\mathrm{HCl}$ pekat dengan pipet didapat hasil penilaian berdasarkan teori dan temuan dilapangan yaitu 2 risiko sebagai berikut:

a. Risiko terhirup uap larutan dengan nilai risiko 150 (substansial), hal ini bisa 
disebabkan karna melakukan praktek belum sesuai SOP, bekerja kurang hatihati dan belum tersedia masker sesuai standart

b. Risiko terkena/ kontak larutan dengan nilai risiko 225 (priority 1), hal ini bisa disebabkan karna tidak pakai sarung tangan karet saat praktek, melakukan praktek belum sesuai SOP dan bekerja kurang hati-hati

Dari 2 risiko diatas bisa berdampak seperti Batuk, tersedak, merusak jaringan sal.pernafasan bagian atas, sensitifitas pada paru-paru apabila terhirup larutan atau Iritasi dan korosif pada kulit, luka bakar, dan dermatitis apabila terkena kulit oleh larutan.

4) Kegiatan Memasukkan larutan ke dalam labu ukur didapat hasil penilaian berdasarkan teori dan temuan dilapangan yaitu 8 risiko sebagai berikut:

a. 1 risiko tergores pecahan kaca dengan nilai risiko 18 (Acceptable), kegiatan ini dapat menimbulkan bahaya fisik/ dampak seperti luka ringan, hal ini disebabkan karna bekerja kurang hatihati

b. 7 risiko terkena larutan dengan nilai risiko 4 substansial (2 nilai 80 , 1 nilai 75 dan 1 nilai 150), 2 priority 3 dengan nilai masing-masing 30 dan 1 Acceptable dengan nilai 15 , dampak dari kegiatan ini bisa iritasi pada kulit dan mata kemungkinan bisa luka bakar, kerusakan kornea bahkan kebutaan terkena larutan $\mathrm{Na}_{2} \mathrm{CO}_{3} / \mathrm{ZnSO}_{4} / \mathrm{MgSO}_{4} /$ $\mathrm{Na}_{2} \mathrm{C}_{2} \mathrm{O}_{4} / \mathrm{H}_{2} \mathrm{C}_{2} \mathrm{O}_{4} / \mathrm{EDTA} / \mathrm{KMnO}_{4}$, hal ini disebabkan bekerja kurang hati-hati, Tidak pakai sarung tanngan karet saat praktek, Melakukan praktek tidak sesuai SOP dan tidak pakai safety googles saat praktek.

5) Kegiatan Menambahkan aquadest ke dalam labu ukur didapat hasil penilaian berdasarkan teori dan temuan dilapangan yaitu 1 risiko priority 3 dengan nilai 20, dapat menimbulkan Bahaya fisik seperti tergores pecahan kaca dampak dari kegiatan ini luka ringan, hal ini bisa terjadi karna kurang hati-hati saat praktikum.

6) Kegiatan Mengocok/membolak-balikkan labu takar didapat hasil penilaian berdasarkan teori dan temuan dilapangan yaitu 1 risiko (acceotable dengan nilai 6), kegiatan inidapat menimbulkan Bahaya fisik seperti tergores pecahan kaca dan dampak dari kegiatan ini luka ringan, hal ini bisa terjadi karna kurang hati-hati saat praktikum.

7) Kegiatan Panaskan air untuk memanaskan larutan $\mathrm{Na}_{2} \mathrm{C}_{2} \mathrm{O}_{4}$ didapat hasil penilaian berdasarkan teori dan temuan dilapangan yaitu 2 risiko (1 priority 3 dengan nilai 30 dan 1 substansial dengan nilai 150), kegiatan inidapat menimbulkan Bahaya fisik seperti terkena air panas dan elektrik, dampak dari kegiatan ini kulit melepuh, merah sedangkan elektrik bisa tersengat listrik, hal ini bisa terjadi karna kurang hatihati saat praktikum.

8) Kegiatan Titrasi didapat hasil penilaian berdasarkan teori dan temuan dilapangan yaitu 4 risiko (2 substansial dengan nilai masing-masing 80 dan 2 priority 3 dengan nilai 30 dan 60 )

Dari kegiatan tersebut dapat menimbulkan Bahaya kimia seperti terkena larutan $\mathrm{HCL}$, EDTA, $\mathrm{KMnO}_{4}$, dan bahaya ergonomi seperti repetitif motion, dampak dari kegiatan ini iritasi pada kulit, luka bakar, terpapar lama dapat menyebabkan kulit terbakar serta dampak ergonomi nyeri dan pegal-pegal, hal ini disebabkan karna Bekerja tidak menggunakan sarung tangan karet dan Hanya menggunakan satu tangan.

Dari 8 kegiatan diatas sejalan dengan penelitian Asmara, Mutiara A. (2012) tentang Analisis Risiko Pada Kegiatan Praktek Kimia Analitik Kuantitatif di Laboratorium Kimia Teknik Metalurgi dan Material Universitas Indonesia.

\section{KESIMPULAN}

Dari hasil analisis risiko Keselamatan dan Kesehatan Kerja (K3) dan penilaian risiko pada laboratorium Kimia Terpadu di Politeknik Kesehatan Padang Kampus Siteba Padang di dapat 35 risiko yaitu Very high (1 risiko), priority 1 (3 risiko), substansial (18 risiko), priority 3 (9 risiko) dan acceotable (4 risiko)

\section{SARAN}

Saran dalam penelitian ini dilakukan untuk masing-masing Tingkat Risiko yaitu untuk hasil risiko Very high (risiko harus dikurangi dengan mewajibkan pakai Alat pelindung diri (APD) sesuai kegiatan, bekerja 
Jurnal Sulolipu : Media Komunikasi Sivitas Akademika dan Masyarakat

Vol. 20 No. 22020

e-issn : 2622-6960, p-issn : 0854-624X

wajib sesuai SOP dan sebelum praktek mahasiswa wajib menguasai materi yang akan dipraktekkan atau apabila tidak diindahkan stop aktifitas/ kegiatan praktek), Priority 1 (membutuhkan tindakan perbaikan segera atau menyediakan dengan segera seperti menyediakan safety googles apabila belum ada dan memperbaiki alat yang rusak segera), Substansial (membutuhkan tindakan perbaikan dengan pelatihan atau menguji mahasiswa yang akan praktek untuk mengetahui apakah mahasiswa sudah menguasai materi atau belum), Priority 3 (membutuhkan alat pelindung diri sesuai dengan kegiatan praktek dan mewajibkan memakai APD setiap akan praktek), Acceptable (Intensitas kegiatan yang menimbulkan risiko dikurangi seminimal mungkin atau mengatur jadwal praktek dengan baik).

Untuk aplikasi dilabor dibuat peraturan seperti: Mahasiswa maupun instruktur/ dosen harus bekerja dengan hati-hati, Lakukan Praktek sesuai dengan SOP, Pada saat pencucian alat mahasiswa harus menggunakan sarung tangan karet dan kaca mata safety agar tidak kerna percikan bahan kimia dan Saat mengambil bahan kimia mahasiswa harus memakai masker N.95.

\section{UCAPAN TERIMA KASIH}

Ucapan terima kasih kami sampaikan kepada Bapak Direktur Politeknik Kesehatan Padang dan Kepala Pusat Penelitian yang telah menfasilitasi Dana dan kebutuhan administrasi dan kepada anggota Tim peneliti yang telah bekerja dengan baik serta semua pihak yang tidak bisa disebutkan satu per satu

\section{DAFTAR PUSTAKA}

Arvina N dan Djunaidi Z. (2012). Penilaian Risiko Keselamatan dan Kesehatan Kerja Pada Proses Kerja di Bagian Trimming Chassis Final F-Series, PT Isuzu Astra Motor Indonesia (IAMI), Assembling Plant Pondok Ungu (APPU). Fakultas Kesehatan Masyarakat Universitas Indonesia Program Studi Sarjana Kesehatan Masyarakat.

Asmara, Mutiara A. (2012). Analisis Risiko Pada Kegiatan Praktek Kimia Analitik Kuantitatif di Laboratorium Kimia Teknik Metalurgidan Material Universitas Indonesia Tahun 2012. Fakultas Kesehatan Masyarakat Universitas Indonesia Program Studi Sarjana Kesehatan Masyarakat: Depok (Skripsi)

AZ/NZS 4360: 2004. Risk Manajement (ISBN 073375804 1)

Dahlan, Sopiyudin M. (2010). Besar Sampel dan Cara Pengambilan Sampel dalam Penelitian Kedokteran dan Kesehatan. Jakarta: Salemba Medika

Dahlan, Sopiyudin M. (2011). Statistik Untuk Kedokteran dan Kesehatan. Jakarta: Salemba Medika

Direktorat Jenderal PP dan PL. (2012). Pedoman Analisis Risiko Kesehatan Lingkungan (ARKL). Jakarta: Kementrian Kesehatan

Direktorat Jenderal Pendidikan Dasar. (2012). Pedoman Pembinaan dan Pengembangan Usaha Kesehatan sekolah (UKS)). Jakarta: Kementrian Pendidikan dan Kebudayaan

Direktorat Jenderal Sumber Daya Iptek dan Dikti. (2016). Pedoman Penilaian Kegiatan Pengembangan Profesi Jabatan Fungsional Pranata Laboratorium Pendidikan (PLP). Jakarta: Kemenristekdikti

Direktorat Bina Kesehatan Kerja dan Olahraga. (2012). Penyakit Akibat Kerja Karena Pajanan Logam Berat. Jakarta: Kementrian Kesehatan.

Direktorat Kesehatan Lingkungan. (2016). Kesehatan Lingkungan Di Sekolah. Jakarta: Ditjen Kesehatan Masyarakat Kementerian Kesehatan RI

Hastono, S. P. (2011). Analisis Data Kesehatan. Depok: Fakultas Kesehatan Masyarakat, Universitas Indonesia. 131-134

http://journal.poltekkes-mks.ac.id/ojs2/index.php/Sulolipu

ILO (2013). Keselamatan dan Kesehatan Kerja (Pedoman Pelatihan untuk manajer dan pekerja) Modul Lima: SCORE, ILO Jakarta $2013 \quad$ (ISBN: 978-92-2-822012-4)

ISO 31000 (2009). Managemen Risiko

Keputusan Menteri Kesehatan No. 876 tahun 2001 tentang Pedoman Teknis Analisis Dampak Kesehatan Lingkungan (ADKL)

Peraturan Pemerintah Republik Indonesia nomor 66 tahun 2014 tentang Kesehatan Lingkungan

Peraturan Bersama Menteri Pendidikan Nasionaldan Kepala Badan Kepegawaian Negara 
Jurnal Sulolipu : Media Komunikasi Sivitas Akademika dan Masyarakat

Vol. 20 No.2 2020

e-issn : 2622-6960, p-issn : 0854-624X

nomor 02 dan Nomor 13/Mei/ 2010 tentang Petunjuk Pelaksanaan Jabatan Fungsional Pranata Laboratorium Pendidikan dan Angka Kreditnya.

Peraturan Menteri Negara Pendayagunaan Aparatur Negara nomor 03 tahun 2010 tentang Jabatan Fungsional Pranata Laboratorium Pendidikan dan Angka Kreditnya.

Peraturan Menteri Kesehatan RI Nomor 32 tahun 2017 tentang Standar Baku Mutu Kesehatan Lingkungan dan Persyaratan Kesehatan Air untuk Keperluan Higiene Sanitasi, Kolam Renang. Solus Per Aqua dan Pemendian Umum

Pusat Pendidikan dan Pelatihan Tenaga Kesehatan. (2012). Modul Pelatihan

Manajemen Laboratorium Bagi Pengelola Laboratorium Pendidikan Tenaga Kesehatan.

Jakarta: BPPSDMK Kementerian Kesehatan

Rahman, A. (2007). Public Health Assessment : Model Kajian Prediktif Dampak Lingkungan dan Aplikasinya untuk Manajemen Risiko Kesehatan. Depok: Pusat Kajian Kesehatan Lingkungan dan Industri FKM-UI.

Rahman, A. (2014). Prinsip Dasar, Metode, dan Aplikasi Analisis Risiko Kesehatan Lingkungan. Depok: Departemen Kesehatan Lingkungan/Pusat Kajian Kesehatan Linkungan dan Industri FKM-UI.

Rahman, A., Hananto, M., Laelasari, E., Adi, H. K., Widodo, S., \& Lasut, D. (2014). Health risk estimates from exposure to minerals in artisanal gold mining site in Gunung Pongkor, Bogor, Indonesia. Depok: in press.

Santoso, H (2014). Kajian Risiko Kesehatan dan Keselamatan Kerja Pada Mill Boiler di Pabrik Gula Pakis Baru Pati, Semarang, Program Studi Teknik Industri Universitas Diponegoro (dalam $1^{\text {st }}$ Annual Conference in Industrial and system Engineering, Semarang 2 Oktober 2014: ISBN:978-979-97571-5-9)

Slamet, J.S..(2009). Kesehatan Lingkungan, Yogyakarta, Gajah Mada University Press

Soemirat, Juli (2010). Epidemiologi Lingkungan. Yogyakarta; Gadjah Mada University Press

Undang-undang nomor 32 tahun 2009 tentang Perlindungan dan Pengelolaan Lingkungan Hidup Undang-undang nomor 36 tahun 2009 tentang Kesehatan

Wardhana, Rico T. (2015). Analisis Risiko Keselamatan dan Kesehatan Kerja (K3) dengan Metode HAZARD ANALYSIS. Fakultas Teknik Universitas Jember Program Studi Strata 1 Jurusan Teknik Sipil: (Skripsi) 